\title{
The Text as Heretic: Mixed Genres and Polemical Techniques in a Refutation of the Mirror of Simple Souls
}

\author{
Justine L. Trombley*
}

This article examines the style and rhetoric of a fourteenth-century treatise written against the condemned mystical work The Mirror of Simple Souls. The treatise addresses thirty-five extracts from the Mirror which are refuted as errors. Rather than merely a list of erroneous propositions, the text is a polemical narrative which employs various genres and literary styles from the canon of anti-heretical writings. The article notes how these various genres are combined to produce a comprehensive condemnation of the Mirror, and examines the rhetoric used to address it. The text is shown to go beyond merely refuting the Mirror's doctrine. It also personifies the text by connecting it to the broader concept of heresy through the use of standard tropes that are usually used to describe the person of the generalised "heretic". This makes it unique in the history of the Mirror's reception, and shows how an anonymous text was assessed and characterised with tactics more often applied to human agents, rather than texts.

Keywords: polemic; anti-heretical texts; Marguerite Porete; The Mirror of Simple Souls; heresy; condemned texts; textual refutation

The Mirror of Simple Souls (Speculum simplicium animarum) is a mystical treatise written as a dialogue between Love, the Soul, and Reason. Originally composed in Old French, the Mirror discusses the Soul's journey to union with the divine. On this journey, the Soul attempts to free itself from both worldly practices - which includes institutional practices such as fasting, sermons, and prayers - and also from its own will, desires, and identity. Through Love's guidance, the Soul is eventually led to the state of "annihilation", in which it dissolves into indistinct union with God. ${ }^{1}$ As is now well known, the Mirror attracted its share of controversy. It was condemned as heretical twice in the early fourteenth century, once in Valenciennes and again a few years later in Paris. Its author, Marguerite Porete, was also condemned and burned at the stake in Paris on 1 June $1310 .^{2}$ Nevertheless, the Mirror survived destruction and circulated anonymously across late medieval Europe in four languages:

* Correspondence details: Email: jltrombl@gmail.com.

I am grateful to the reviewers and to Sita Steckel for their very helpful comments and criticisms.

1 For the Middle French and Latin texts, see Porete, Mirouer des Simples/Speculum, ed. Guarnieri and Verdeyen. For the modern English see Porete, Mirror of Simple Souls, trans. Babinsky, and Porete, Mirror of Simple Souls, trans. Colledge et al.

2 For a full account of Marguerite's trial see Field, Beguine, the Angel, and the Inquisitor. 
Latin, Italian, Middle English, and French. In apparent contrast to its fate in Valenciennes and Paris, numerous readers accepted it as beneficial spiritual reading in the late fourteenth and early fifteenth centuries. ${ }^{3}$ But this positive reception did not represent a total triumph of the Mirror over its critics. Its Latin version in particular continued to attract suspicion and opposition. ${ }^{4}$ The Latin, now thought to have been possibly produced in Southern France between the years 1300-1317 - fairly early in the Mirror's circulation - had the broadest geographical circulation of the Mirror's linguistic traditions. ${ }^{5}$ It had a particularly robust circulation in Italy, and it is there where new suspicions and condemnations of the Mirror appeared in the fifteenth century. Between the years 1417-1439, the Mirror was denounced in sermons, banned from certain monastic congregations, confiscated from citizens, and caught up in an inquisition. ${ }^{6}$

While this contentious history shows how the Mirror could sharply divide opinion, it has not so far produced evidence that readily marks it for inclusion in a special issue on polemics. ${ }^{7}$ While a single, clear definition of polemic is difficult to give, on a general level it can be defined as discourse which involves controversy and confrontation. ${ }^{8}$ More specifically, it can be an exchange in which an attacker asserts the "truth " of their position against that of an opponent using hostile language, often in the form of a debate. ${ }^{9}$ Texts written to combat heresy frequently took this latter form. The classic examples of anti-heretical polemics are those texts written against Cathars and Waldensians in the thirteenth century, where an "orthodox" attacker took on the "heretical " enemy in order to disprove error. ${ }^{10}$ In these quasi-dialogic texts, the error of the heretic was the springboard from which the polemicist launched a counterargument that would both refute error and present the truth of Church doctrine. As part of the process, the author constructed a »living " opponent, the rhetorical heretic expounding his error. ${ }^{11}$

3 For an overview of the Mirror's various linguistic circulations see the essays in Stauffer and Terry (eds.), Companion to Marguerite Porete, 155-292.

4 Trombley, Mirror Broken Anew.

5 On the Latin's early origins see Trombley, New Evidence, 147-150, and Piron, Marguerite, 86-88. On the manuscripts of the Latin tradition and their distribution see Trombley, Latin Manuscripts, 186-217 and also Trombley, New Frontiers.

6 For an overview of these denunciations see Guarnieri, Movimento del Libero Spirito, 466-476; Sargent, Medieval and Modern Readership, 93-96; Trombley, Latin Manuscripts, 206-217.

7 This article was first presented as a paper at the 2015 Leeds International Medieval Congress as part of the thematic strand »Religious Polemics Compared".

8 Hettema and Van der Kooij, Introduction, xiii

9 Southcombe et al., Introduction, 6. For more on types and forms of religious polemics, see Dascal, On the Uses of Argumentative Reason, 3-20.

10 On this genre, see Sackville, Heresy and Heretics, 13-40.

11 Sackville, Heresy and Heretics, 37. As Dascal points out, these texts were a type of "staged polemic «, in which the audience (the reader) is only a witness and not a participant. The author decides how to present his opponent's stance and works for the achievement of his own goals. Dascal, On the Uses of Argumentative Reason, 8. 
Although there was plenty of hostility shown to the Mirror, most of the efforts directed against it do not fit into this kind of anti-heretical polemic. In the records of Marguerite's trial and execution three of the Mirror's errors are mentioned and presented as proof of its heresy, but are not engaged with or refuted at any length. ${ }^{12}$ Similarly, the denunciations in Northern Italy are short references, not constituting any lengthy discourse. A slightly more sustained refutation can be found in a fifteenth-century manuscript, on folios 26r-32r of Vatican, Biblioteca apostolica vaticana, MS Vat. lat. 4953. Here there is a list of the Mirror's errors which are followed by short refutations. ${ }^{13}$ There are at least thirty points taken from a Latin translation of the Mirror which are systematically refuted in an almost bullet-point like style, where citations are merely lined up one after the other as counter-proofs to the Mirror's own assertions. Yet while the Vatican text demonstrates opposition to and doctrinal concern over the Mirror, it is not a polemic; it belongs more to the genre of error lists, a common way of condemning texts which often took place in academic heresy investigations and condemnations. ${ }^{14}$ The text and only the text is addressed, and it offers a succinct demonstration of error with little elaboration. While this, like many anti-heretical polemics, was concerned with addressing specific theological errors, it does not take on the dialogic, debate-like style which engaged with an opponent, nor does it employ much hostile language or imagery. No such extended discourse has previously been found in connection with the Mirror, either in its first two condemnations at Valenciennes and Paris, or in its later circulations.

But a recently re-discovered text, found on folios 215v-221v of Padua, Biblioteca universitaria, MS 1647, changes this. This codex, owned by the fifteenth-century Paduan professor of canon law Giacomo de Zocchi, is a legal compilation, containing also a Decretals commentary, decisions from the Roman Rota, and a text from the Council of Constance..$^{15}$ The text in question appears on the last seven folios of the codex. Although watermark evidence shows it was copied in the early fifteenth century in Bologna, internal textual evidence suggests that its original composition likely took place sometime before $1317 .{ }^{16}$ This means that it was composed very near to Marguerite's trial and execution, or possibly even before this event. ${ }^{17}$ At first glance, the text appears to be of the same character as the Vatican list: it presents thirty-five extracts from a Latin Mirror of Simple Souls and refutes each one in turn using mostly canon-legal and scriptural citations. Its original author is, for now, unknown, but its heavy reliance on canon law implies that it was written by a canon lawyer, one who had no knowledge of the Mirror's origins and authorship. ${ }^{18}$ Whether he composed this text on commission or on his own initiative is uncertain, but the tone of the piece suggests he took the

12 For the trial documents see Verdeyen, Procès d'inquisition, 47-94. For the English translations see Field, Beguine, the Angel, and the Inquisitor, 209-231.

13 This list was edited and published in Guarnieri, Movimento del Libero Spirito, 649-660. This list possibly originated from a consultation on the Mirror that was solicited from theologians at the University of Padua in 1437. See Guarnieri, Movimento del Libero Spirito, 474-475, and Trombley, Latin Manuscripts, 195-197.

14 See Koch, Philosophische und theologische Irrtumslisten, 423-450; Courtenay, Inquiry and Inquisition, 168-181; and Thijssen, Censure and Heresy.

15 Trombley, New Evidence, 140. On Giacomo de Zocchi see Griguolo, Per la biografia.

16 At the moment, it is not certain where its original composition took place. For a more detailed description of this manuscript and the evidence establishing the text's early date of origin see Trombley, New Evidence, 137-152. I am currently working on both an edition of this text and an in-depth study of it as part of a monograph.

17 Trombley, New Evidence, 149-150.

18 Trombley, New Evidence, 146. 
task on himself. ${ }^{19}$ Its pre-1317 date of composition means that its refutations of the Mirror were constructed without reference to the Clementine decree Ad nostrum. This decree, which was promulgated with the rest of the Clementines in 1317, became the standard text used to identify and refute sfree spirit $<$ heretics in the fourteenth and fifteenth centuries. ${ }^{20}$ It was also the standard text used to criticise the Mirror in the fifteenth century. ${ }^{21}$ The author of this Paduan text does, however, see in the Mirror the same issues which Ad nostrum would address, namely: indifference to moral guidance and practice of the virtues; the rejection of Church practices such as fasting, prayers, sermons, etc.; the self-acquisition of divine knowledge without dependence on scripture or other authorities; and the ability of the human Soul to achieve a state of divinity. ${ }^{22}$ Therefore, this text offers an intriguing glimpse into how a Mirror critic constructed his arguments against it before a "pre-packaged « condemnation like Ad nostrum was available for reference.

While the Vatican error list also shows concern over these same issues, when examined more closely the Paduan text in fact differs significantly from that of the Vatican. It has a narrative style, more like a treatise than a list. The citations are not laid out in a list-like format, but are rather part of a larger explanatory discourse that has a distinct, individual authorial voice. Upon further scrutiny, it becomes clear that the author engages with the Mirror on both a doctrinal and a rhetorical level in the manner of a polemic. It most closely resembles the anti-heretical polemics of the thirteenth century, in that it takes the form of a statement-and-response which presents heretical error in order to refute it and reaffirm orthodox interpretation. But rather than fitting into any single genre or making use of any one technique, it instead seems to meld several different ones together. The result is a work which draws upon multiple existing formats and rhetorics to make a single polemic against both the Mirror as a text, and the Mirror as a heretical person. This article will explore the construction of the Paduan text, examining how it mixes genres, how it addresses the Mirror on a rhetorical level, and how the author constructs and characterises an anonymous, disembodied text in a way that presents it as a dynamic - and dangerous - opponent.

As noted above, the author was in all likelihood a canon lawyer; the majority of quotations and citations which he uses - aside from his scriptural ones - are canon-legal, and not theological. His approach to the text is extremely literal. He seems to have little tolerance for the metaphorical and paradoxical language of mysticism, and takes the Mirror's statements at face value. ${ }^{23} \mathrm{He}$ begins the text by copying out the first error from the Mirror, taken from chapter $5 \cdot{ }^{24}$ But, rather than immediately refute the error, he initially sets it aside and instead begins with what is essentially a short legal consilium on the question of the text's overall

20 On Ad nostrum's use see Lerner, Heresy of the Free Spirit; Kieckhefer, Repression of Heresy, 21-32; and Lerner, Meister Eckhart's Specter, 115-134. The Latin and English of Ad nostrum can be found in Makowksi, When is a Beguine not a Beguine?, 93-95.

21 See Trombley, New Evidence, 147-148. The Vatican error list does make use of Ad nostrum in its refutations. See Guarnieri, Movimento del Libero Spirito, 649-660.

22 Trombley, New Evidence, 142-143.

23 Trombley, New Evidence, 145.

24 Mirouer des Simples/Speculum, 19-21. The chapter division is that used by Guarnieri and Verdeyen. 
legitimacy. He begins with a question: "It seems the position which ought to be questioned concerning this little work is whether it should be received (recipiendum) by the Church. $\aleph^{25}$ This forms the central question that drives his argument. From there, he proceeds to answer it point by point, using primarily legal citations, to show why the book cannot be accepted as good spiritual reading, showing clear similarities to the consilium format. ${ }^{26} \mathrm{He}$ lays out three main points, each one supported with various citations from Gratian's Decretum, the Liber Extra, the Liber Sextus, and the occasional scriptural quotation. The three points, connected by the theme of legitimacy, build upon one another. First, it cannot be received because it is apocryphal, that is, its origins and authorship are entirely unknown. ${ }^{27}$ This point on authority then blends into the second, more serious charge: it cannot be accepted because it is new doctrine entirely taken from the author's own head and none of its arguments are supported by scripture or the doctors of the Church. This connects it to the essential legal definition of a heretic found in Gratian. ${ }^{28}$ Thirdly and finally, not only does the Mirror produce new doctrine, but it is disseminating this doctrine with no mandate from the Church, and therefore usurps authority from the Church. ${ }^{29}$ These arguments establish a judgment on the text's overall legitimacy before the author even addresses the text directly. This provides a legal underpinning to the detailed refutations which follow, marking the text out as unacceptable from the beginning.

When he does turn to the Mirror's specific contents at the end of his short consilium - "Now we come to the text of this little work" - he shifts to a different technique for the main body of his treatise. ${ }^{30}$ Having established a baseline of illegitimacy for the text on legal grounds, he moves from addressing the question of the book as a whole to attacking and refuting the specific errors found within it. Here he takes up a polemical format, a scholastic statement-and-response familiar from the anti-heretical polemics of the thirteenth century. In those texts, the author summarises the heretical position and then uses it as a launch point for his refutation. In the anti-Mirror text, direct quotations from the Mirror itself serve this purpose. ${ }^{31}$ While a few extracts here and there are paraphrased, the text is largely reproduced

25 MS 1647, fol. 215v: De hoc opusculo positio quaerendum videtur an sit ab ecclesie recipiendum. "Received« or perhaps also "accepted « in this case seems to mean whether it can be accepted as true or authoritative and appropriate religious reading. This usage of recipere in relation to texts is probably echoing the language of Gratian's $15^{\text {th }}$ distinction, dealing with approved and unapproved texts, given that this is discussed in the text immediately following. See Gratian, Decretum Magistri, D. 15 c. 3, ed. Friedberg, 36-40.

26 See for comparison the consilia in Parmeggiani, I consilia procedurali, 1-215.

27 MS 1647, fol. 215v. Here the author cites Gratian's 15th distinction (D. 15 c. 3), where several apocryphal works are listed and described as texts that "Catholics should avoid« (a catholicis vitanda sunt). Gratian, Decretum Magistri, ed. Friedberg, 36-40. While mapocryphal« did not automatically mean heretical, it did cast doubt or suspicion on the text's truth and authority. For a discussion of medieval definitions of "apocryphal« see Dzon, Cecily Neville and the Apocryphal Infantia salvatoris, 267-271.

28 MS 1647, fol. 215v. The canons cited are C. 24 q. 3 c. 27 and 28. Gratian, Decretum Magistri, ed. Friedberg, 997-998

29 MS 1647, fol. 215v.

30 MS 1647, fol. 215v. Nunc ad textum huius opusculi veniamus. The use of the diminutive »opusculum « could possibly indicate that this author had a shorter version of the Mirror in front of him - and there is some textual evidence to suggest this, see Trombley, New Evidence, 142, n. 23 - but it could also merely have been a physically small codex, as in the cases of the Mirror copies found in Vatican, Biblioteca apostolica vaticana, MSs Vat. lat. 4355, Chigianus B IV 41, Rossianus 4, and Chigianus C IV 85, none of which are over $215 \mathrm{~mm}$ in length.

31 In its fifteenth-century copy, the Mirror quotations are clearly distinguished from the rest of the text by being written in a larger, neater hand separated by a space above and below. 
verbatim from a Latin Mirror copy, as the text more or less matches the readings in other Latin Mirror manuscripts, and other direct quotations are occasionally used in the midst of a refutation to provide clarification or further support to the argument. ${ }^{32}$ This indicates that he was working from an actual copy of the Mirror, rather than merely a set list of extracts. ${ }^{33}$

Anti-heretical polemics often had two purposes: the main purpose of attacking error, and the embedded purpose of demonstrating orthodox truth. ${ }^{34}$ In a text such as Moneta of Cremona's Summa adversus catharos et valdenses or Alain of Lille's De fide catholica, various heretical positions are explained, and then are shown to be false with counterarguments supported by scriptural and theological citations; these counterarguments simultaneously provide "correct « interpretation and doctrine. ${ }^{35}$ This is clearly the case in the Paduan text. The latter aim, the demonstration of truth, is made explicit before the treatise itself even begins. Written above the text at the top of the work's first folio, folio $215 \mathrm{v}$, is a quotation from 1 Corinthians 11:19, one common to discourse on heresy: »For there must also be heresies, so that those who are approved may be made manifest $« .{ }^{36}$ In the main body of the text after his opening legal assessment, the author takes precisely this route. His refutations, supported by canon-legal, biblical, and occasional theological citations, both prove the error of the Mirror and edify the reader as to correct doctrine. A good example can be found in his response to the fifth error, which comes from Chapter 8 of the Mirror, in which it states that the Simple Soul still possesses the Virtues, but is free from service to them, and that the Virtues instead now serve the Simple Soul. ${ }^{37}$ The author of the polemic dismisses this construction as the Soul trying to have it both ways. One either lives temperately or intemperately, he states, and there is no middle ground between vice and virtue, citing as proof Gratian's 32nd Causa. ${ }^{38} \mathrm{He}$ then notes that if the Simple Souls do not have the practice of the Virtues, then they are outside the status of salvation, and if outside the status of salvation, they are outside of God's love, because:

32 Further discussion of the relationship between the Paduan Mirror extracts and the text of other Latin Mirrors can be found in Trombley, New Evidence, 141-142.

33 Trombley, New Evidence, 142. This is also indicated by the author's remark near the beginning of his treatise that if one makes an inspection "from the beginning of this little work all the way up to the end " (a primo huius opusculi usque in finem) it becomes clear its author made everything up from his own head. MS 1647, 215v.

34 See Sackville, Heresy and Heretics, 41.

35 For excerpts of these texts see Wakefield and Evans, Heresies of the High Middle Ages, 214-220 and 301-329.

36 MS 1647, fol. 215v.: Oportet et hereses esse, ut qui probati sunt manifesti fiat. On this passage see Grundmann, »Opportet et haereses esse«. Forthcoming in an English translation in Grundmann, Essays on Heresy.

37 MS 1647, fol. 216v; found in Mirouer des Simples/Speculum, 29.

38 MS 1647, fol. 216v. The specific citation is C. 32 q. 1 c. 9. See Gratian, Decretum Magistri, ed. Friedberg, 1117. 
'Wisdom will not enter into a malicious soul, nor dwell in a body subject to sins [Wisdom 1:4]. Additionally, there are two forces in the Soul: One is higher, that is reason, through which God wishes man to comprehend the might of the works of God and his name, and to praise and glorify his works, [as in] Ecclesiasticus 17[:7-8]. He wished that the lower part, which is sensuality, to be subservient to reason, which is the higher part, but not the reverse...Again, there are two [things] necessary to salvation, namely to recede from evil and to do good, whence the prophet asks in Psalms 33[:13]: 'Who is the man who desires life? Who chooses to see the good days? «, and below, responding: 'Decline from evil and do good<, etc. [Psalms 36:27]. Thus it is not possible to do good except by behaving virtuously. ${ }^{39}$

The instructive purpose here is clear, and it achieves both aims. The claim of the Simple Soul is shown to be wrong with canon law and scriptural evidence, and such evidence "manifests « the truth: that the Virtues are necessary to living a good life and to achieving salvation. This is the prevailing format for the rest of the treatise, and by the end the Mirror has been shown to be "false, deceitful, and heretical«, and several "truths" have been reinforced: the necessity of obedience to the Church, the inability of man to achieve divine status in the present life, the importance of the sacraments to achieving salvation, and many others. Therefore we see the author of this text pivoting from a purely legal demonstration of the book's illegitimacy to a demonstration of the book's doctrinal illegitimacy through refutation of its contents, in the manner of a scholarly polemic.

This latter technique, of course, is not remarkable in and of itself, either within an antiheretical context or in broader medieval intellectual debates. But the author brings in other elements which make intriguing modifications to it. In addition to adding the legal judgment at the beginning, the author also engages in a construction of the Mirror not just as a text, but as an opponent. Embedded in his doctrinal refutations are also attacks on the Mirror's character, and he uses rhetoric usually used against a person or group. The Mirror is not addressed merely as an object or a vehicle for scholarly refutation and discourse, but is also animated to serve as a rhetorical opponent. This characterisation does not necessarily maintain the distinct images of "author" and "text«, but presents something more ambiguous.

At the beginning of the text, in his consilium-esque introduction, the author does initially address the Mirror in strictly text-and-author terms. He immediately notes that the work is apocryphal, because its origins and its author are completely unknown, and although it may contain some truths, it nevertheless contains many falsehoods, and therefore cannot be accepted. He directs the reader to the legislation on apocryphal books and unaccepted texts found in Gratian's fifteenth distinction, a copy of the sixth-century Gelasian decree..$^{40}$ The Mirror's authorial anonymity weakens the text's legitimacy; what is more, he declares that

39 MS 1647, fol. 216v.: "In malivolam animam non introibit sapientia, nec habitabit in corpore subdito peccatis". Preterea due sunt vires anime: una superior, que est ratio, per quam voluit deus hominem cognoscere magnalia operum dei et nomen eius, et opera laudare et glorificare, Eccleisiastici xvii. Voluit quod inferiorem partem, que est sensualitas, subservire rationis, que est superior pars, non autem econtra.... Item duo sunt necessaria ad salutem, scilicet recedere a malo et facere bonum unde propheta quaerens psalmi xxxiii: "Quis est homo qui vult vitam diligit dies videre bonos?" et subdit respondendo "recedere a malo et fac bonum ", etc. Constat autem non posse fieri bonum nisi virtuose agendo.

40 Gratian, Decretum Magistri, D. 15 c. 3, ed. Friedberg, 36-40. The author's use of this distinction seems to be primarily focused on showing how texts with obscure origins have no authority, rather than to include the Mirror in any of the specific groups of texts which are named in the canon. 
the Mirror's doctrines are entirely from the author's own head, without any support from Scripture or the doctors of the Church. Here he uses a quote from Augustine, found in Gratian's ninth distinction, which describes how texts ought not to be believed unless they are proven to be true through scripture or other legitimate authorities. ${ }^{41}$

These are arguments based firmly in textual and authorial legitimacy, and form the first two points of this first section: false doctrine and illegitimacy. But after this initial focus on text and author, the refuter begins to shift to a less distinct separation.

The shift begins with the author bringing in standard legislation regarding the person of a heretic. He notes that the Mirror's lack of support from legitimate authorities means that it is new, invented doctrine, which connects it to the essential definition of a heretic as found in the 27th and 28th canons of Gratian's 24th Causa.$^{42}$ These canons, mainstays of anti-heretical legislation, define a heretic as essentially one who understands Scripture other than how it ought to be interpreted, and who brings forth and follows new opinions ${ }^{43}$ From there he moves to the third focus of his legal assessment: illicit dissemination. Not only is the Mirror false doctrine, but its dissemination of such doctrine doubly marks it as heretical. Here he invokes the image of a false preacher, one who publicly proclaims unsupported doctrine and usurps a role solely designated to churchmen. "How shall they preach, unless they be sent?" he writes, invoking Romans 10:15. As other sects were, the Mirror is cast here as usurping an office of the church in order to spread false doctrine. ${ }^{44}$ It is also specifically cast within the verbal, physical action of preaching. His supporting citation is the 1199 decree Cum ex iniuncto, which, among other things, condemned those who preached without the authority to do so. ${ }^{45} \mathrm{He}$ finishes his consilium with a quotation from Hebrews 13:19: „Be not led away by various and strange doctrines. "By using this line, the author offers a neat cap to the main picture of the Mirror that he has presented in his introduction. The Mirror is an apocryphal, unsupported work, which, like a false preacher, is usurping church office and disseminating "various and strange« doctrines illicitly, which could dangerously "lead away « those reading or hearing it.

In the very beginning of the treatise, then, the Mirror is first presented in terms which characterise both a text - as with the reference to apocrypha and textual authority - and a human agent, as with the image of the false preacher and the "classic « heretic found in Gratian. Obviously, the author of the Paduan text would have been aware that a text has a human author behind it. But near the end of this section, particularly when using the image of the false preacher, his characterisation begins to blur the lines between the two. Is the author the false preacher, or is that the Mirror itself? Is the image of a false preacher merely being used as a representative of illicit dissemination in general, constituted by the text's very existence, or does he envision it - or has he perhaps witnessed it - being read aloud or spread about in other ways? He does not clearly make this distinction by always using the terms "author" or »text«, he merely lets the citations he uses speak for themselves.

\section{1}

43 Gratian, Decretum Magistri, C. 24 q. 3 c. 27, and 28, ed. Friedberg, 997-998; On these canons in the broader antiheretical legal landscape, see Sackville, Heresy and Heretics, 104-107.

44 See, for example, Alain of Lille's criticism of the Waldensians, in Wakefield and Evans, Heresies of the High Middle Ages, 217-220. See also the analysis in Kienzle, Preaching as Touchstone.

45 See Hagender et al., Register Innozenz' III, 273.

medieval worlds • No. $7 \cdot 2018 \cdot 137-152$ 
This foreshadows the rest of his treatise, for on a rhetorical level he does not consistently maintain a dual focus on text and human agent. Instead, he frequently addresses the »human" side of the Mirror, presenting it as an active agent of heresy. Only a few times does the Paduan author refer to the Mirror as »the text« or »little work" (opusculum). In most cases, he addresses the "speaker" of the text itself, but not always as "author" (auctor). The author of the polemic more often employs pejoratives to describe the speaker, which convey a more dynamic figure than simply the image of an author. He unsurprisingly uses »this heretic" (iste hereticus) regularly, but also frequently employs "this wicked spirit" (iste malignus spiritus) and "tartarean [i.e. infernal] spirit" (spiritus tartareus). There is a "voice» at work in the text, such as when he calls one of the Mirror's assertions a »diabolical voice" (vox diabolica) akin to that of Satan in the Garden of Eden. ${ }^{46}$ Who exactly the author envisions as this "voice" is not consistent. Sometimes it seems as though it is a generic "he", a heretic who is speaking about the Simple Soul. But at other points he appears to see the Simple Soul itself as the speaker. The »bestial Soul« (bestialis anima) or "wretched Soul« (infelix anima) "scoffs" (insultat) at the Virtues, "wraps itself in carnal desires" (se involuit concupiscentiis carnalibus), and speaks its doctrines "with a filthy mouth" (polluto ore). The Soul wants to eat and drink and indulge all while expecting to enter heaven without any other works of penance or contrition. ${ }^{47}$ Both images of the Mirror's voice seem to blend together. Both of them also move away from that of a static text and towards the idea of an active agent of heresy.

The blending of person and text is perhaps made clearest in the closing paragraph of the work. Here the author sets down a judgment of the Mirror, writing "We prosecute this heretic with his work, and we relinquish this heretic with his work to be burned by fire « ${ }^{48}$ Here, in the final lines of his polemic, the author does not just pronounce upon the text, but upon "this heretic with his work«, and furthermore mentions the heretic first, then the text. He is also echoing inquisitorial language here, by using relinquimus for "relinquish", a word usually used by inquisitors when they turned condemned heretics over to secular authorities in the expectation that they would then be burned at the stake. Therefore, by the end of the treatise, the author is no longer just referring to an illegitimate text, but now speaks of a heretic and his work, as if there is an identifiable figure which can be sentenced along with his text, even though the text itself is the only "heretic « present.

It is in this personifying construction of the book that he brings in another technique which, though common to anti-heretical discourse in sermons, exempla, and other writings, generally does not often appear in the kind of scholarly refutation format used here, nor in the condemnation of texts. He draws on the classic images and tropes used to characterise the general idea of "the heretic", and employs them frequently and with great energy. These add to his personification of the Mirror, as these topoi were usually used to describe the person of the heretic. ${ }^{49}$ These are embedded in his refutation of doctrinal error, providing a rhetorical counterpart to the legal and intellectual exercises of judgment, disproving error, and revealing truth.

46 MS 1647, fol. 219v.

47 MS 1647, fols. 218v and 220v.

48 MS 1647, fol. 221v.: Hunc hereticum con suo opere persequimur, et hunc hereticum cum suo opere relinquimus igne cremandum.

49 For a summary of these tropes see Sackville, Heresy and Heretics, 154-190. See also Kienzle, Preaching as Touchstone, 45-50, and Grundmann, Typus des Ketzers, 91-107, forthcoming in English translation in Grundmann, Essays on Heresy. 
His attacks are sharp and vitriolic. They are not separate points against the Mirror but are instead woven into and underpin his refutations, adding emotional weight to his intellectual argument. The tropes which occur most frequently are licentiousness, false appearance, corruption, and diabolical inspiration. Abandoning the Virtues provokes the charge of licentiousness. The Simple Soul, which has admitted vice by rejecting the Virtues, "wraps itself in carnal desires " and "cleaves to the flesh and to its works or fruits " (adhesit carni et operibus seu fructibus)..$^{50}$ The Soul eats the »bread of idleness « from Proverbs 31:27..$^{51}$ "Better», he adds, "that it had eaten knowledge of the divine from learned men, than of such barbarous arrogance, and in its ignorance be plunged into the abyss of hell. $\aleph^{52}$ When the Mirror says that the Soul does not seek after anything which is illicit, he declares its real motive to be the desire of illicit things, since its rejection of the Virtues means that it can only desire that which is forbidden and unlawful. ${ }^{53}$

This same statement contains another trope, the image of craftiness and false appearance that first appeared with the mention of the false preacher. He writes that, in saying the Soul does not desire anything which is prohibited, "a snake lurks« in the words of the Mirror, because this qualifying statement implies that the Soul is merely putting up a smokescreen to hide its true desires for illicit, carnal things. ${ }^{54}$ At other points, it is marked as one of those who are of a "double heart " and is the sinner who "goeth on the earth two ways « from Sirach 2:14. ${ }^{55}$ The indifference of the Annihilated Soul to things such as poverty, shame, penances, or honour, is cast in this same light. A claim to indifference based on unity with the divine is "making excuses in sin ", quoting Psalms 140:4, and the Soul's ambivalence is actually just laziness and wantonness. ${ }^{56}$ Its claim to unity is a deception: "It dares to say it is in unity and divinity. I say that it is not united in love, but in the unity of a slave. Those who say such things bring ruin, and may they be ashamed. May death come over them, and may they descend living into hell. « ${ }^{57}$

The trope of corruption is also frequently used, describing the Mirror's assertions as "venom" and "poison" which are "vomited out". The Simple Soul is "manured with so many vices" (tot vitiis stercorata) and presumes to be in heaven "in the dung of the vices" (in stercore vitiorum), and it is fixed deep in "muck" (limo), without any inward cure of good works or salvation. ${ }^{58}$ The author also adds a diabolical element. He makes repeated reference to the Mirror's »devilish tricks« and »diabolical cunning« or »diabolical arts«. Its

50 MS 1647, fols. 220r, 218v.

51 MS 1647, fol. 215v, fols. Manducabit ergo anima ista panem ociosum.

52 MS 1647, fol. 215v.: Melius fuerat ergo manducasse scientiam divinorum a doctis quam in tantam efferi superbiam, et in sua ignorata in profundum inferni dimergi. Arrogance (superbia) was also a telltale sign of the heretic. See Grundmann, Typus des Ketzers, 94-95.

53 MS 1647, fol. 217r.

54 MS 1647, fol. 217r.: Hic latet anguis in verba.

55 MS 1647, fol. 217r.

56 MS 1647, fol. 218v.

57 MS 1647, fol. 220r.: Presumit dicere se in unitatam in divinitatem. Non dico unitate amoris sed unitate serve. Confundantur et erubescant qui ista dicunt. Veniat mors super illos et descendant in infernum uiuentes.

58 MS 1647, fols. 218r and 219r. 
father is the devil, and it maliciously rejects Church teachings and induces people to sin. In claiming that the Soul can become God in indistinct union with the divine, it, like Lucifer, arrogantly aspires to be Godlike, and like the serpent in Eden tempts others to $\sin .^{59}$

These are much more personified images and tropes, and they cast the Mirror's assertions more in the "voice " of an active opponent than an inanimate text. Furthermore, as the intensity of his rhetoric shows, these attacks are not made dispassionately. The author conveys a strong level of emotion, namely scorn, anger, and outrage. He pours an enormous amount of effort into expounding upon the Mirror's filth, its association with the devil, and its falsity.

The tropes he uses are all familiar from other anti-heretical discourses, but, as L. J. Sackville has pointed out, they were sparingly used in the scholarly polemics, which addressed "the content of the heresy, and not the condition of the heretic «. ${ }^{60}$ Furthermore, these tropes were traditionally applied to the person of a heretic, rather than a text. Even when the writings of a particular author were of concern - such as Bernard of Clairvaux's attack on Peter Abelard, where he lamented the "poisonous pages" of his books which "fly abroad « - it is nevertheless the author who is being addressed as the heretic. ${ }^{61}$ But in the Paduan text, the discourse is not presented in the strict image of a heretical "author" generating a text; the heretic here is a rather more blurred and blended figure.

This text, therefore, combines three different identifiable genres/polemical techniques: the legal consilium, the scholarly refutation of doctrinal error, and the classic tropes of antiheretical discourse aimed at the person of the heretic. This reveals layers of purpose. Each technique on its own leaves a gap, but used together each one fills the other's gaps and makes a comprehensive condemnation of the Mirror. He answers the question of the Mirror's overall legitimacy with a legal judgment, but only on the basis of its obscure origins, its inability to be proven by any authority, and its usurpation of the office of preaching. This leaves the challenges of its specific heresies unanswered. He then employs scholarly polemic in order to refute the Mirror's errors and show it to be false and illegitimate on a doctrinal level on top of a legal one.

The third level, the personifying, rhetorical one, seems at first glance to be almost superfluous, an extra frill on the more technical legal and doctrinal polemic. Other anti-heretical polemics constructed rhetorical heretics in which to ground their counter-arguments, but here one would expect the Mirror's excerpts to sufficiently serve that purpose. Instead, the author makes the seemingly unnecessary effort to provide the rhetorical heretic in addition to the text. But in essence this is an important third weapon in the author's textual arsenal. To him, the Mirror was a completely anonymous, apocryphal work. It was not linked to any individual or sect, and so it was a disembodied text which was not anchored to any broader recognisable heresy. In the absence of any known figure, the author constructed one himself. The way in which the Mirror is addressed creates a "living " figure who not only provides a more dynamic opponent for his arguments, but it also underpins the disembodied text with the classic image of "the heretic«. By painting it with the tropes of the generic heretic, the Mirror is no longer a single erroneous book, but is a manifestation of the larger, ever-present enemy of heresy. As a technique, this more fully solidifies his case against the Mirror. If the creator and animating force of the Mirror is an »evil spirit « with all the recognisable

59 MS 1647, fol. 219v.

60 Sackville, Heresy and Heretics, 37 and 39.

61 See Peters, Heresy and Authority, 88. 
hallmarks of a heretic, then this places the final seal upon both its legal and doctrinal illegitimacy. Its errors are not merely wrong and in need of correction, but are the dangerous, "poisonous « words of a "diabolical voice". This means that, by the time the reader gets to the end of the treatise, the impression of the irredeemably evil Mirror is firmly established. This makes the judgment that the heretic and the work ought to be "burned by fire seem both appropriate and necessary.

In addition to refuting the Mirror on all levels, this genre-mixing was perhaps also generated by necessity. As noted above, this text was probably written before 1317 . This means that, at the time of writing, the Mirror would have been a relatively new text, as it is thought to have been composed in the last decade of the thirteenth century, and then perhaps re-written or revised in the first decade of the fourteenth. ${ }^{62}$ Additionally, as noted above, the polemic was likely written before the publication of the Clementine decrees, and therefore before Ad nostrum was available for consultation. Therefore, when the author of this polemic was first confronted with the Mirror, it may not yet have been associated with any particular identifiable heresy, and it had no known author. ${ }^{63}$ Unlike the texts of Cathars, or, later, »beghardian « texts or texts of the Hussites or Lollards, which could be condemned on the basis of their association with certain individuals or known heresies, there was not yet any existing precedent against which the Mirror could be weighed other than more generic declarations on heresy and heretics. This would in a sense demand a more comprehensive approach to its refutation and condemnation, as the case against it had to be built from the ground up.

At the moment, there is no solid evidence pointing to the specific motives and context behind the composition of this text. But these techniques may help to shed a bit more light on them. The Mirror appears in this text as very much a danger, which has the potential to lure others into its error and which promotes and disseminates false doctrine. The author's powerful rhetoric and effort to condemn it on all levels convey a sense of urgency. There is a need here to show the Mirror to be, in his words, "false, deceitful, and heretical " on all levels. The polemic's accusations of deceit and temptation, and its connection of the Mirror to the broader landscape of heresy, hint at something more than rhetoric. It perhaps indicates a concern that that the Mirror had already attracted and influenced a large number of readers. We know from its fifteenth-century Italian circulation that the Latin Mirror circulated across a number of different social circles - lay, semi-religious, and religious - so it is not impossible that in its earlier circulation it appealed to a similarly diverse audience. ${ }^{64}$ The concern driving this text was likely not merely over the Mirror's circulation among the general populace, but amongst learned and religious circles as well. This same diversity in audience for the Mirror may account for the Paduan text's techniques, perhaps indicating that the polemic's own intended audience was both within and outside scholarly circles.

62 Field, Beguine, the Angel, and the Inquisitor, 54; Piron, Marguerite in Champagne, 136-138.

63 As explained in Trombley, New Evidence, 151, it is unlikely that this polemic is associated with Marguerite Porete's two condemnations and trial. Additionally, the author's lack of knowledge of Marguerite and the Mirror's condemnations means he was likely based far enough away from Paris and Valenciennes that no news of these events had reached him.

64 See Guarnieri, Movimento del Libero Spirito, 466-476; Sargent, Medieval and Modern Readership, 93-96, and Trombley, Latin Manuscripts, 206-217; and Trombley, New Frontiers. 
This kind of polemical treatment is - as far as is known - unique in the Mirror's reception history. MS 1647 provides insight into how the Mirror was characterised on a rhetorical level, how in the minds of its opponents it could connect to a broader discourse on heresy, and how it could evoke an emotional and rhetorical response alongside an intellectual one. But it also provides an intriguing deviation from both traditional anti-heretical polemic and the condemnation of texts. In the thirteenth-century polemics, while heretical texts were used in constructing the opposing rhetorical heretic, they serve more as pieces of a larger whole, rather than the sole target of attack. ${ }^{65}$ Even in cases where a specific text is mentioned, as in Salvo Burci's Liber suprastella and Rainerius Sacconi's Summa de catharis et pauperibus de Lugduno, these texts still belonged to the larger, recognisable Cathar heresy, products of heretics rather than independent cases of heresy themselves. ${ }^{66}$ In the case of specific texts being condemned, this often took the form of lists of erroneous propositions rather than polemical discourses, as noted at the beginning of this article. While these condemnations were aimed at texts, it was often - though not always - in connection with the university environment and the teaching of propositions. These propositions were also not always taken from a single text, but drawn from a number of the author's writings. ${ }^{67}$ Text and author were on the whole kept separate, with the author usually escaping severe punishment while the propositions or books were condemned. A condemnation of both text and author as heretical in the same moment - much less wholly diabolical and deserving of execution - was a rare occurrence. ${ }^{68}$ In the polemic found within MS 1647, instead of merely treating the text as just a text, it instead is made to function as both erroneous text and rhetorical heretic, the text as heretic.

A more detailed and wider-ranging comparison of techniques between those used against heretical persons and those used against texts is a subject which merits further study. For now, what we have in MS 1647 offers an interesting case of the two mingling together. It shows a confluence of various anti-heretical polemical tools within one text: the legal, the scholarly, and the rhetorical. What it also reveals is an anonymous text cast in the role of "the heretic", characterised with language and imagery more often used against people. In the absence of an identifiable author, one was constructed, built out of the assertions the Mirror itself made and out of broader definitions and tropes of what a heretic is. The author of the Paduan document mixes styles and creates an image of the Mirror of Simple Souls which is simultaneously that of a heretical text requiring assessment and refutation, and a heretic to be pursued and burned.

65 Sackville, Heresy and Heretics, 26-28.

66 For editions of these texts see Burci, Liber suprastella, ed. Bruschi; Sacconi, Summa, ed. Šanjek.

67 Koch, Philosophische und theologische Irrtumslisten, 423-450; Courtenay, Inquiry and Inquisition, 168-181; Lists were also used for non-academic texts, as can be seen with the case of Nicholas Eymerich's list of Ramon Lull's errors in his Directorium Inquisitorum and the errors taken by Heinrich von Kamp from two libelli written by »beghards«. See Nicholas Eymerich, Directorium Inquisitorum, 256-261; Preger, Beiträge zur Geschichte, 62-63.

68 Despite her execution, this process applied to Marguerite Porete's trial in 1310 as well. Sean Field has shown how carefully William of Paris kept apart judgments on Marguerite's person from judgments on her book, bringing the two together only at her sentencing; and even there, Field points out that it is Marguerite's relapse and contumacy which brings about her condemnation, rather than the content of her book. See Field, Beguine, the Angel, and the Inquisitor, 85-105,125-126. 


\section{References}

Courtenay, William, Inquiry and Inquisition: Academic Freedom in Medieval Universities, Church History 58 (1989) 168-181.

Dascal, Marcelo, On the Use of Argumentative Reason in Religious Polemics, in: Hettema, Theo L. and Van der Kooij, Arie (eds.), Religious Polemics in Context: Papers Presented to the Second International Conference of the Leiden Institute for the Study of Religions Held at Leiden, 27-28 April 2000 (Assen, 2004) 3-20.

Dzon, Mary, Cecily Neville and the Apocryphal Infantia Salvatoris in the Middle Ages, Mediaeval Studies 71 (2009) 235-300.

Field, Sean L., The Beguine, the Angel, and the Inquisitor: The Trials of Marguerite Porete and Guiard of Cressonessart (Notre Dame, IN, 2012).

Gratian, Decretum Magistri Gratiani, ed. Emil Friedberg, Corpus Iuris Canonici, Vol. 1 (Leipzig, 1879). Accessed through the Münchener DigitalisierungsZentrum of the Bayerische Staatsbibliothek. [Accessed 2017 and 2018]

Griguolo, Primo, Per la biografia del canonista ferrarese Giacomo Zocchi († 1457): L'insegnamento, la famiglia, i libri, Quaderni per la storia dell'università di Padova 44 (2011) 181-209.

Grundmann, Herbert, Der Typus des Ketzers in mittelalterlicher Anschauung, in: Kultur- und Universalgeschichte: Festschrift für W. Goetz (Leipzig, 1927) 91-107.

Grundmann, Herbert, »Oportet haereses esse.« Das Problem der Ketzerei im Spiegel der mittelalterlichen Bibelexegese, Archiv für Kulturgeschichte 45 (1963) 129-164.

Grundmann, Herbert, Essays on Heresy, Inquisition, Literacy, ed. Jennifer Kolpacoff Deane, trans. Steven Rowan (York Medieval Press) forthcoming.

Guarnieri, Romana, Il movimento del Libero Spirito, Archivio Italiano per la Storia Della Pietà 4 (1965) 353-708.

Hagender, Othmar, Maleczek, Werner, and Strnad, Alfred A. (eds.), Die Register Innocenz' III, Vol. 2: 2, Pontifikatsjahr 1199/1200. Texte (Vienna, 1979).

Hettema, Theo L., Van der Kooij, Arie, Introduction, in: Theo L. Hettema and Arie Van der Kooij (ed.), Religious Polemics in Context: Papers Presented to the Second International Conference of the Leiden Institute for the Study of Religions Held at Leiden, 27-28 April 2000 (Assen, 2004), xi-xv.

Kieckhefer, Richard, The Repression of Heresy in Medieval Germany (Liverpool, 1979).

Kienzle, Beverly Mayne, Preaching as Touchstone of Orthodoxy and Dissidence in the Middle Ages, Medieval Sermon Studies 42 (1999) 18-53.

Koch, Josef, Philosophische und Theologische Irrtumslisten von 1270-1329. Ein Beitrag zur Entwicklung der Theologischen Zensuren, in: Josef Koch (ed.), Kleine Schriften 2 (Rome, 1973) 423-450.

Lerner, Robert E., The Heresy of the Free Spirit in the Later Middle Ages (2nd edition) (Notre Dame, IN, 1991).

Lerner, Robert E., Meister Eckhart's Specter: Fourteenth-Century Uses of the Bull In agro dominico Including a Newly Discovered Inquisitorial Text of 1337, Mediaeval Studies 70 (2008) 115-134.

Makowski, Elizabeth, When Is a Beguine not a Beguine? Names, Norms, and Nuance in Canonical Literature, in: Böhringer, Letha, Kolpacoff Deane, Jennifer, and van Engen, Hildo (eds.), Labels and Libels: Naming Beguines in Northern Medieval Europe (Turnhout, 2014) 93-94. 
Marguerite Porete, Le Mirouer des Simple Ames/Speculum Simplicium Animarum, ed. Romana Guarnieri and Paul Verdeyen, Corpus Christianorum Continuatio Mediaevalis 69 (Turnhout, 1986).

Marguerite Porete, The Mirror of Simple Souls, trans. Ellen Babinsky (New York, 1993).

Marguerite Porete, The Mirror of Simple Souls, trans. Edmund Colledge, Judith Grant, and Jack C. Marler (Indiana, 1999).

Nicholas Eymerich, Directorium Inquisitorum F. Nicolai Eymerici Ordinis Praed. Cum commentariis Francisci Pegñae (Rome, 1587).

Parmeggiani, Riccardo, I consilia procedurali per l'inquisizione medievale 1235-1330 (Bologna, 2011).

Peters, Edward, Heresy and Authority in Medieval Europe (Philadelphia, 1980).

Piron, Sylvain, Marguerite, entre les béguines et le maîtres, in: Sean L. Field, Robert E. Lerner, and Sylvain Piron, (eds.), Marguerite Porete et le Miroir des simples âmes: Perspectives historiques, philosophique, et littéraires (Paris, 2013) 69-101.

Piron, Sylvain, Marguerite in Champagne, Journal of Medieval Religious Cultures 43/2 (2017) 135-156.

Preger, Wilhelm, Beiträge zur Geschichte der religiösen Bewegung in den Niederlanden in der 2 Hälfte des 14 Jahrhunderts, Abhandlungen der historischen Classe der Königlich Bayerischen Akademie der Wissenschaften 21 (1898) 1-63.

Rainerius Sacconi, Summa de Catharis et Pauperibus de Lugduno, ed. Franjo Šanjek, Archivum Fratrum Praedicatorum 44 (1974) 31-60.

Sackville, Lucy J., Heresy and Heretics in the Thirteenth Century: The Textual Representations (York, 2011).

Salvo Burci, Liber suprastella, ed. Caterina Bruschi, Fonti per la storia dell'Italia medievale, Antiquitates 15 (Rome, 2002).

Sargent, Michael, Medieval and Modern Readership of Marguerite Porete's Mirouer Des Simples Ames Anienties: The Manuscripts of the Continental Latin and Italian Tradition, in: Alessandra Petrina (ed.), The Medieval Translator/Traduire Au Moyen Age: In Principio Fuit Interpres 15 (Turnhout, 2013) 85-96.

Southcombe, George, Suerbaum, Almut and Thompson, Benjamin Introduction, in: George, Southcombe, Almut, Suerbaum and Benjamin Thompson, (eds.), Polemic: Language as Violence in Medieval and Early Modern Discourse (Farnham, 2015).

Stauffer, Robert, and Wendy, Terry R., A Companion to Marguerite Porete and the Mirror of Simple Souls (Leiden, 2017).

Thijssen, Johannes M. M. H., Censure and Heresy at the University of Paris: 1200-140o (Philadelphia, 1998).

Trombley, Justine, The Mirror Broken Anew: The Manuscript Evidence for Opposition to Marguerite Porete's Latin Mirror of Simple Souls in the Later Middle Ages. Unpublished PhD thesis (University of St Andrews, 2014).

Trombley, Justine, New Evidence on the Origins of the Latin Mirror of Simple Souls from a Forgotten Paduan Manuscript, Journal of Medieval History 43/2 (2017) 137-152.

Trombley, Justine, The Latin Manuscripts of the Mirror of Simple Soul, in: Robert Stauffer and Wendy R. Terry (eds.), A Companion to Marguerite Porete and the Mirror of Simple Souls (Leiden, 2017) 186-217. 
Trombley, Justine, New Frontiers in the Late Medieval Reception of a Heretical Text: The Implications of Two New Latin Copies of Marguerite Porete's Mirror of Simple Souls, in: Michael D. Bailey and Sean L. Field, (eds.), Late Medieval Heresy: New Perspectives, Studies in Honor of Robert E. Lerner (Woodbridge, UK, 2018) forthcoming.

Verdeyen, Paul (ed.), Le procès d'inquisition contre Marguerite Porete et Guiard de Cressonessart, Revue d'histoire ecclesiastique 81 (1986) 47-94.

Wakefield, Walter L. and Austin P. Evans (eds.), Heresies of the High Middle Ages (New York, 1969).

\section{Manuscripts}

Padua, Biblioteca universitaria, MS 1647

Vatican, Biblioteca apostolica vaticana, MS Vat. lat. 4953

Vatican, BAV, MS Vat. lat. 4355

Vatican, BAV, MS Rossianus 4

Vatican, BAV, MS Chigianus B IV 41

Vatican, BAV, MS Chigianus C IV 85 